\title{
OPTIMIZATION OF PENSION COMPANIES IN THE CZECH REPUBLIC
}

\author{
EVA TOMÁS̆KOVÁ
}

\begin{abstract}
This paper presents pension system in the Czech Republic, analysis public income, and expenditure connected with pension system and existing supplementary pension funds. It shows the return of pension funds and profit of pension companies and new rules connected with activities and profit of pension companies. The main goal of this paper is to know if public expenditure spent on pension insurance in pension funds of pension companies are optimally expended. Description, analysis, and synthesis are the scientific methods used for processing the paper.
\end{abstract}

\section{Keywords}

Pension system; pension companies; pension funds; optimization; public expenditures

\section{JEL Classification: H55, H75, G22}

\section{Introduction}

The Czech Republic ranks to the developed countries with the lengthening of life and number pensions. The future predictions show that this situation will probably not change. This positive situation is connected with negative impacts on public finance. It is obvious that current public incomes assigned for pensions system will not be enough and state pensions will be very low. Even now, it is possible to see the discrepancy between public incomes and public expenditures. From this reason, some of the people try to insure for pensions and they choose many ways.

1 Doctor, Department of Financial Law and Economics, Faculty of Law, Masaryk University, Czech Republic. The Author specializes in Public Finance and Market Orientation. Contact email: eva.tomaskova@law.muni.cz. 
They invest finance to properties (e. g. realities, precious metals, pieces of jewelry, the object of art) or they have a lot of children (they take care of their parents) or they choose one of the companies offered voluntary supplementary personal pension (named "third" pillar). Every one of these possibilities is characterized by advantages and disadvantages. In addition to these advantages and disadvantages, there are a lot of unnamed risks, future for many people is unbeknown, and they want to solve that.

The main goal of this paper is to know if public expenditure spent on pension insurance in pension funds of pension companies are optimally expended. Description, analysis, and synthesis are the scientific methods used for processing the paper.

\section{Pension System in the Czech Republic}

Pension system in the Czech Republic is divided into two parts. First, mandatory basic pension insurance is funded on a running basis and it is covering employees and the self-employed. The system is characterized as universal and provides for all economically active individuals. The rules of the system are the same for all insured persons and all of industries except power sector, which are e. g. policemen, customs officers, firefighters or soldiers. This first pillar is in the competence of the Ministry of Labor and Social Affairs. The main substantive law regulation, which aims at the entitlement to a pension from the basic pension insurance, methods of determination of pension benefits and conditions of payment, is the Act no. 155/1995 Coll., on pension insurance. This regulation came into effect on 1 January 1996. The contribution rate for the first pillar is $28 \%$. Both, employers and employees contribute to this system (employers pay $21.5 \%$ of payroll, employees $6.5 \%$ of earnings. The self-employed pay the full height of contribution rate. The relation of earnings and pensions has a strong redistributive character. According to Pension Funds Online, the base on which pensions are assessed is 100\% up to CZK 8400 . $30 \%$ between CZK 8 400-20 500, and 10\% above this sum. Table 1 shows the main information about the first pillar in numbers.

Table 1 Summary About First Pillar

\begin{tabular}{|l|c|c|c|}
\hline \multicolumn{1}{|c|}{ Index } & $\mathbf{3 0 . 0 9 . 2 0 1 5}$ & $\mathbf{3 0 . 0 9 . 2 0 1 6}$ & $\mathbf{3 0 . 0 9 . 2 0 1 7}$ \\
\hline Number of old-age pensioners & 2370725 & 2389270 & 2396784 \\
\hline Average of pension (in CZK) & 11334 & 11441 & 11828 \\
\hline Number of taxpayers for one old-age pensioner & 2,14 & 2,15 & 2,19 \\
\hline Total incomes from insurance & 260,88 & 276,38 & 299,23 \\
\hline
\end{tabular}


Optimization of Pension Companies in the Czech Republic

\begin{tabular}{|l|c|c|c|}
\hline Total outcomes to pensions & 282,91 & 291,33 & 303,34 \\
\hline Deficit between incomes and outcomes & $-22,03$ & $-14,94$ & $-4,11$ \\
\hline
\end{tabular}

Source: Own processing according to Czech Social Security Administration.

It is possible to see, that all indexes are increasing during the watched period except deficit of pension system. The reason for decreasing of the deficit between incomes and outcomes is that the economics is increasing; taxpayers pay for pension insurance more than at the time of economic crisis. Alarming is that today's, we need 2.19 taxpayers for paying pension for one old-age pensioner and this trend does not change. This situation is unsustainable. Unfortunately, it is not political motivation for change.

Second, there is a voluntary complementary additional pension insurance with state contributions marked as the third pillar of the pension system. The third pillar also includes products offered by commercial insurance companies - particularly life insurance. The pension companies are joint stock companies and they have to lead the business under the provisions of the Commercial Code. The third pillar is in the competence of Ministry of Finance. All pension companies have to be licensed by the Ministry of Finance, in agreement with the Ministry of Labour and Social Affairs and the Securities Commission. This system is based on products offered by commercial insurance funds. It is possible to choose pension fund and height of contributions. Pensions granted from this third pillar create only negligible part of incomes of the retired.

The state contributes to pension insurance in the third pillar. The state contribution is depending on the level of employees' contributions. For member contributions between CZK 300-399, the state adds CZK 90 plus $20 \%$ of the member contribution above CZK 300. If the pension plan member contributes between CZK 400-499, the state adds CZK 110 plus $20 \%$ of the member contribution above CZK 400 . The allowance gradually increases with the highest allowance (CZK 230) for members contributing more than CZK 1000. Employers can contribute to your employees.

Pension funds are not Authorized to offer more than one pension plan. It is possible to switch pension funds for participants; there are no switching fees. The minimum age for receiving of payments from pension funds is 60 , provided a minimum number of contributory years, which is regulated by each pension fund. If the participants want to receive the money from the pension fund earlier, the state matching contributions have to be repaid and there is additional taxation. Participants can choose if they money in the form of regular installments or as a lump sum, more details are on Pension Funds Online. 
The number of pension insurance in the third pillar is decreasing during the last three years. The highest number of pension insurance was in 2012 (5 134 862), the reason was in a number of new pension insurance, which was increasing about $146.8 \%$ in comparison 2011, see Table 2.

Table 2 Development of Pension Insurance in the Czech Republic

\begin{tabular}{|c|c|c|c|c|c|c|}
\hline & & 2011 & 2012 & 2013 & 2014 & 2015 \\
\hline \multirow{2}{*}{$\begin{array}{l}\text { Pension } \\
\text { insurance }\end{array}$} & Number & 4565741 & 5134862 & 4963344 & 4803134 & 4643016 \\
\hline & $\begin{array}{c}\text { Increase } \\
\text { (\%) }\end{array}$ & 0.8 & 12.5 & -3.3 & -3.2 & -3.3 \\
\hline \multirow{2}{*}{$\begin{array}{l}\text { New pension } \\
\text { insurance }\end{array}$} & Number & 457033 & 1128020 & 77771 & 145841 & 156062 \\
\hline & $\begin{array}{c}\text { Increase } \\
\text { (\%) }\end{array}$ & -7.8 & 146.8 & -93.1 & 87.5 & 7 \\
\hline \multirow{2}{*}{$\begin{array}{l}\text { Pension } \\
\text { insurance with } \\
\text { employers' } \\
\text { contributions }\end{array}$} & Number & 1271934 & 1317563 & 1352461 & 1354485 & 1362283 \\
\hline & $\begin{array}{c}\text { Increase } \\
\text { (\%) }\end{array}$ & -1 & 3.6 & 2.6 & 0.1 & 0.6 \\
\hline \multirow{2}{*}{$\begin{array}{l}\text { State } \\
\text { contributions } \\
\text { to pension } \\
\text { insurance }\end{array}$} & $\begin{array}{l}\text { Volume } \\
\text { (mld CZK) }\end{array}$ & 5.602 & 5.913 & 6.861 & 6.847 & 6.803 \\
\hline & $\begin{array}{c}\text { Increase } \\
\text { (\%) }\end{array}$ & 1.7 & 5.6 & 16 & -0.2 & -0.7 \\
\hline \multirow{2}{*}{$\begin{array}{l}\text { Total members' } \\
\text { contributions }\end{array}$} & $\begin{array}{c}\text { Volume } \\
\text { (mld CZK) }\end{array}$ & 23.426 & 25.493 & 33.306 & 32.897 & 32.667 \\
\hline & $\begin{array}{l}\text { Increase } \\
\text { (\%) }\end{array}$ & 0.9 & 8.8 & 30.6 & -1.2 & -0.7 \\
\hline \multirow{2}{*}{$\begin{array}{l}\text { State contribution } \\
\text { (average per } \\
\text { month) }\end{array}$} & $\begin{array}{l}\text { Volume } \\
\text { (CZK) }\end{array}$ & 105 & 108 & 117 & 120 & 124 \\
\hline & $\begin{array}{c}\text { Increase } \\
\text { (\%) }\end{array}$ & 0.4 & 2.5 & 8.4 & 2.8 & 3 \\
\hline \multirow{2}{*}{$\begin{array}{l}\text { Members' } \\
\text { contribution } \\
\text { (average per } \\
\text { month) }\end{array}$} & $\begin{array}{l}\text { Volume } \\
\text { (CZK) }\end{array}$ & 442 & 465 & 570 & 579 & 598 \\
\hline & $\begin{array}{c}\text { Increase } \\
\text { (\%) }\end{array}$ & 0.5 & 5.3 & 22.6 & 1.7 & 3.1 \\
\hline
\end{tabular}

Source: Own processing according to Basic indexes of development of pension insurance. Ministry of Finance of the Czech Republic.

Table 2 shows that state contributions to pension insurance are decreasing in the last three years in CZK 6,8 milliard in 2015. The same situation was at a total volume of members' contributions, the highest was in 2013. State contribution per month as well members' contribution per month is increasing during the watched period. State contributions to pension insurance reached more than 6,8 milliard in 2015. State contribution per month reaches $20,7 \%$ of members' contribution per month. 
It is possible to see, that the state contributions to members of the third pillar to the third pillar with a lot of money.

According to Association of Pension Companies in the Czech Republic, current average members' contribution per month was 614 CZK at the end of September 2017. A number of participants in the third pillar are $4,47 \mathrm{mil}$. and the total volume of contributions in the third pillar is 405,5 milliards CZK.

Pension insurance system in the Czech Republic absents the second pillar. The second pillar is usual in the EU member states. The second pillar was possible to use between 2013 and 2016. The main reason for scrapping the second pillar was lack of interest of persons. Only 83000 persons signed up. The main steps for scrapping the second pillar was realized in 2016. Incomes to this pillar were flowed from two sources, from gross wages, and from the first pillar. Participants have to send $2 \%$ from gross wages and employers have to send $3 \%$ of the $28 \%$ first pillar social contribution. Increasing of payment from gross wages was unpopular. The monies in the second pillar were transferred to the first pillar. Members of the second pillar had the choice of receiving their money into private bank accounts or reinvest the money into existing third pillar companies.

\section{Commercial Companies Offered Pension Insurance}

Pension insurance offers pension companies according to the Act no. 42/1994 Coll., on State-Contributory Supplementary Pension Insurance. Pension companies have the possibility of gathering and controlling the money of participants in the pension fund or more pension funds according to Act no. 427/2011 Coll., on Supplementary Pension Savings.

According to Ministry of Finance, total 49 commercial insurance companies offered their services on the market in the Czech Republic during 1995 and 2017. Today, eight commercial insurance companies can offer commercial pension insurance in the Czech Republic. The rest of commercial insurance companies were fused, are in bankruptcy or liquidation or are marked as defunct companies. Table 3 shows the biggest companies according to the number of clients. It involves only clients, which make a contract in the period November 2013 - September 2017. Total number of participants during this period is 711 thousand.

Table 3 Pension Companies according to Number of Clients

\begin{tabular}{|c|c|}
\hline Pension company & Number of clients \\
\hline Česká spořitelna - penzijní společnost & 223627 \\
\hline
\end{tabular}


Eva Tomášková

\begin{tabular}{|c|c|}
\hline Penzijní společnost České pojištovny & 163830 \\
\hline ČSOB penzijní společnost & 110586 \\
\hline KB penzijní společnost & 110064 \\
\hline Allianz penzijní společnost & 35861 \\
\hline
\end{tabular}

Source: Tůma, O. Doplňkové penzijní spořeni. Jak si letos vede nové penzijko.

Number 1 in pension companies is Česká spořitelna - penzijní společnost with 223 627 participants. It is $31 \%$ of the total number of participants. Penzijní společnost České pojišstovny places on the second position with $23 \%$. ČSOB penzijní společnost and KB penzijní společnost are both more than 15\%. The market rate of the rest pension companies (according to a number of clients in the presented period) is small.

Pension companies offer different types of pension funds. Conservative types of pension funds buy especially bonds, dynamic or increasing types of pension funds buy more stock. Profit and risk of the first type of pension funds are low, profit and risk of the second type of pension fund are higher. Preference of pension funds can be known according to the size of assets of pension companies. Table 4 shows the biggest 5 pension funds.

Table 4 Biggest Pension Funds according to Assets

\begin{tabular}{|c|c|}
\hline Pension company & Assets (milliards CZK) \\
\hline Česká spořitelna: Conservative fund & 6,063 \\
\hline Česká pojištovna: Saving fund & 5,058 \\
\hline Česká spořitelna: Balanced fund & 2,603 \\
\hline ČSOB: Conservative fund & 2,285 \\
\hline KB: Conservative fund & 2,029 \\
\hline
\end{tabular}

Source: Tůma, O. Doplňkové penzijni spoření. Jak si letos vede nové penzijko.

Table 4 shows that conservative funds and saving fund reach the most size of assets. It is paradox because people want to have enough money in old age, but they prefer conservative funds with the low level of returns. The only small portion of participants prefers dynamic funds with high returns.

The high size of assets involves pension funds of Česká spořitelna. Conservative fund and balanced fund place on the first and third position. It is obvious that pension company Česká spořitelna is the most dynamic in comparison with the other pension companies. Pension company Česká spořitelna has the most part of new clients and two of its pension funds have the high size of assets. One of the pension funds of Česká pojišt'ovna places on the second position. It is the same position as at previous table evaluating the number of clients. Conservative fund of $\breve{C} S O B$ is on 
the fourth position. The total range of ČSOB (according to a number of clients and size of assets) is the third position. The fourth position belongs to pension companies Komerční banka.

Current pension companies offered pension insurance in the Czech Republic with the funds are shown in Table 5. This Table shows the performance of pension fund in 2016 and performance from the beginning of pension fund.

\section{Table 5 Performance of Pension Companies}

\begin{tabular}{|c|c|c|c|c|c|c|c|}
\hline $\begin{array}{l}\text { Pension } \\
\text { company }\end{array}$ & Pension fund & $\begin{array}{l}2016 \\
(\%)\end{array}$ & $\begin{array}{l}\text { Total }^{*} \\
(\%)\end{array}$ & $\begin{array}{l}\text { Pension } \\
\text { company }\end{array}$ & Pension fund & $\begin{array}{l}2016 \\
(\%)\end{array}$ & $\begin{array}{l}\text { Total }^{*} \\
(\%)\end{array}$ \\
\hline \multirow{3}{*}{$\begin{array}{l}\text { Allianz } \\
\text { penzijní } \\
\text { společnost }\end{array}$} & $\begin{array}{l}\text { Conservative } \\
\text { fund }\end{array}$ & -0.04 & 3.98 & \multirow{3}{*}{$\begin{array}{l}\text { Česká } \\
\text { spořitelna } \\
\text { penzijní } \\
\text { společnost }\end{array}$} & $\begin{array}{l}\text { Conservative } \\
\text { fund }\end{array}$ & -0.05 & 2.25 \\
\hline & Balanced fund & 2.21 & 9.5 & & Balanced fund & 5.17 & 9.69 \\
\hline & Dynamic fund & 1.51 & 11.5 & & Dynamic fund & 7.42 & 14 \\
\hline \multirow{3}{*}{$\begin{array}{l}\text { AXA penzijní } \\
\text { společnost }\end{array}$} & $\begin{array}{l}\text { Conservative } \\
\text { fund }\end{array}$ & 0.02 & 3.8 & \multirow{4}{*}{$\begin{array}{l}\text { KB Penzijní } \\
\text { společnost }\end{array}$} & $\begin{array}{l}\text { Conservative } \\
\text { fund }\end{array}$ & -0.15 & 1.91 \\
\hline & Obligation fund & 0.43 & 4.38 & & Saving fund & 0.45 & 0.81 \\
\hline & Balanced fund & 4.48 & 12.3 & & Balanced fund & -0.84 & 5.4 \\
\hline \multirow{3}{*}{$\begin{array}{l}\text { Conseq } \\
\text { penzijní } \\
\text { společnost }\end{array}$} & $\begin{array}{l}\text { Conservative } \\
\text { fund }\end{array}$ & 0.09 & 2.7 & & Dynamic fund & 0.87 & 10.8 \\
\hline & Obligation fund & 1.94 & 11.1 & \multirow{3}{*}{$\begin{array}{l}\text { NN Penzijní } \\
\text { společnost }\end{array}$} & $\begin{array}{l}\text { Conservative } \\
\text { fund }\end{array}$ & 0.21 & 1.02 \\
\hline & Joint-stock fund & 10.81 & 49.2 & & Balanced fund & 2.44 & 1.93 \\
\hline \multirow{5}{*}{$\begin{array}{l}\text { ČsOB } \\
\text { Penzijní } \\
\text { společnost }\end{array}$} & $\begin{array}{l}\text { Conservative } \\
\text { fund }\end{array}$ & 0 & 5.05 & & Inreasing fund & 9.35 & -3.3 \\
\hline & Guaranteed fund & -0.47 & 3.17 & \multirow{4}{*}{$\begin{array}{l}\text { Penzijní } \\
\text { společnost } \\
\text { České } \\
\text { pojištovny }\end{array}$} & $\begin{array}{l}\text { Conservative } \\
\text { fund }\end{array}$ & -0.1 & 4.2 \\
\hline & Balanced fund & 3.11 & 11.6 & & Saving fund & 0.8 & 7.5 \\
\hline & \multirow{2}{*}{ Dynamic fund } & \multirow{2}{*}{5.36} & \multirow{2}{*}{17.9} & & Balanced fund & 3.5 & 10.4 \\
\hline & & & & & Dynamic fund & 6.4 & 11.8 \\
\hline
\end{tabular}

* Total performance since the beginning of the pension fund

Source: Tůma, O., Velké srovnání výsledků fondů doplňkového penzijního spoření za rok 2016. 
These pension funds showed the most performance in 2016: Joint-stock fund of Conseq penzijní společnost (10.81\%), Increasing fund of NN penzijní společnost (9.35\%) and Dynamic fund of Česká spořitelna penzijní společnost (7.42\%). The situation in 2017 showed only small changes, pension fund on the first position moved to the second position and the pension fund on the second position moved to the first position. According to the results in September 2017, the first position belongs to Increasing fund of NN penzijní společnost. It shows performance at $12.5 \%$. The second position belongs to Joint-stock fund of Conseq penzijní společnost with $9.5 \%$. Dynamic fund of Česká spořitelna penzijní společnosti is again on the third position with $9.05 \%$. Detailed information is available in Tůma, O. Doplňkové penzijní spoření. Jak si letos vede nové penzijko.

These pension funds showed the highest total performance (since the beginning of pension fund): Joint-stock fund of Conseq penzijní společnost (49.16\%), Dynamic fund of ČSOB Penzijní společnost (17.92\%) and Dynamic fund of Česká spořitelna penzijní společnost (13.95\%). The situation did not change in 2017. According to the result in September 2017, Join-stock fund of Conseq penzijní společnost reached the first position with $62.29 \%$. Dynamic fund of ČSOB Penzijní společnost had performance on $25.11 \%$. Dynamic fund of Česká spořitelna penzijní společnost increased total performance on $21.81 \%$.

Opposite, pension funds with the low level of performance in 2016 were: Balanced fund of KB penzijní společnost with loss $0.84 \%$, Guaranteed fund of ČSOB penzijní společnost with loss $0.47 \%$ and Conservative fund of KB penzijní společnost with loss 0.15 . There are next three pension funds with losses. It means that $22 \%$ of pension funds showed the loss in 2016. Only $74 \%$ of pension funds showed returns because Conservative fund of ČSOB penzijní společnost showed 0 . The situation was not improved in 2017. The worst performance showed guaranteed fund of ČSOB penzijní společnost with loss 1.01\%, Conservative fund of Allianz penzijní společnost with loss $0.99 \%$ and Balanced fund of Allianz penzijní společnost and Conservative fund of NN penzijní společnost, both with loss $0.8 \%$. Unfortunately, $55.5 \%$ of pension funds showed losses in 2017 (till 30 September). The main reason is that returns of government bonds are very low $(0.25 \%$ at 10 -Year bonds in September 2017). The highest interests of 10 -Year bonds were $0.62 \%$ in 2016 , see Slapnička.

Interests of conservative types of pension funds should be higher than the inflation. Inflation was $0.7 \%$ in 2016 and $2.5 \%$ in 2017 in the Czech Republic.

These pension funds showed the lowest performance (since the beginning of pension fund) in 2016: Increasing fund of NN penzijní společnost with loss 3.26, Saving fund of KB penzijní společnost with profit 0,81 and Conservative fund of 
KB penzijní společnost with profit 1.91. In 2017, pension funds with the lowest level of performance are the same as pension funds in 2016. Saving fund of KB penzijní společnost with profit $0.23 \%$ placed in the first position. Conservative fund of KB penzijní společnost with profit $1.21 \%$ was in the second position. Conservative fund of NN penzijní společnost with profit $1.42 \%$ ranged on the third position. Detailed information is available in Tůma, O. Doplňkové penzijní spoření. Jak si letos vede nové penzijko.

One reason for the low profit is that interest rates were very low, however, there is still question if the pension funds could not have better profit. Profit of pension funds influences profit of pension companies. On the first view, all pension companies reached the profit in 2016. Allianz penzijní společnost had the highest profit - more than 744 thousand CZK. The second position ranked Penzijní společnost České pojišt'ovny. These two companies reached about $64 \%$ of total profits of this industry, see Table 6.

Table 6 Profit After Taxes at Pension Companies

\begin{tabular}{|l|c|c|c|}
\hline \multicolumn{1}{|c|}{ Profit after taxes (in thousand CZK) } & $\mathbf{2 0 1 6}$ & $\mathbf{2 0 1 5}$ & $\mathbf{2 0 1 4}$ \\
\hline Allianz penzijní společnost & 744988 & 809447 & 1041879 \\
\hline AXA penzijní společnost & 113293 & -29081 & -97258 \\
\hline Conseq penzijní společnost & 12646 & -2339 & -3239 \\
\hline ČSOB penzijní společnost & 143406 & 82202 & 34199 \\
\hline Česká spořitelna penzijní společnost & 139802 & 52393 & 44805 \\
\hline KB penzijní společnost & 234400 & 175569 & 134974 \\
\hline NN penzijní společnost & 86794 & 121277 & 81744 \\
\hline Penzijní společnost České pojištovny & 651898 & 355903 & 367183 \\
\hline
\end{tabular}

Source: Annual reports of pension companies.

The highest profit on the market reached Allianz penzijní společnost. It is interesting, that Allianz did not rank among pension companies with high number of clients and their pension funds reach the lowest profit, but it is on the second position in total profit. Penzijní společnost České pojištovny places on the first position. It can be marked as balanced company. It has high number of clients, high size of assets and financial results of its pension funds are not so bad. In comparison with the profit in previous year, the worse profit was showed by Allianz penzijní společnost and NN penzijní společnost. Profit of the other pension companies is increased.

How is it possible that in many cases, pension funds reach loss or low level of profit and the total profit of pension companies is increasing? Since 2016, the fee for administration money in pension funds for closed contracts before 2013 has 
been increased in $0,8 \%$ (in 2015 was the fee for administration $0,6 \%$ ). The reward from the profit of pension funds for contracts before 2013 has been decreased from $15 \%$ to $10 \%$ since 2016 see $\S 60$ Act no. 427/2001 Coll. about on Supplementary Pension Savings. Generally, this situation is better for pension companies because the interest rate is still low. According to the Association of pension companies in the Czech Republic, increasing fee for administration brings more than 650 million. CZK to all pension companies for a one year. Lower rewards from the profit of pension funds create about 277 million. CZK for all pension companies for a one year. According to Hovorka, the results is increasing returns about 375 million. CZK in a year. The situation is changed for the closed contract in 2013 and after. The fee for administration increased from $0.8 \%$ to $1 \%$ except for conservative funds. Rewards from a profit of pension funds increased from $10 \%$ to $15 \%$.

Pension companies promised that this change will be better for their clients as well because pension companies will buy "more expensive" investments with the high rate of return. Change of the rules is shown at changing the portfolio of investments in pension funds in 2016 (Slapnička, 2017):

- Increasing of term deposits and current accounts (from 17.61\% to $23.48 \%$ ).

- Decreasing of investments to bonds OECD and MFI (from $15.21 \%$ to $13.33 \%)$.

- Increasing of investments to bonds the other countries (from $12.27 \%$ to $16.55 \%)$.

- Increasing stock (from $8.77 \%$ to $12.16 \%$ ).

- Increasing investments to unit trust (from $1.22 \%$ to $1.76 \%$ ).

According to the results in 2016 and 2017 (preliminary results), this change in returns of pension funds was not shown.

Owners of these eight pension companies are mostly foreign companies. Profits of the pension companies are often transferred to their parent companies. For example, profits of all pension funds offered by KB Penzijní společnost were very low in 2016. However, the company KB Penzijní společnost reached the high level of profit (234,4 mil. CZK) in 2016. The similar situation was at Allianz penzijní společnost. This company reached total profit 744,988 million CZK in 2016.

Both named pension companies are subsidiary companies of foreign parent companies. This activity leads to redistribution of incomes between poor and rich people. Pension funds are buying government bonds of the Czech Republic, see Table 7. 
Optimization of Pension Companies in the Czech Republic

Table 7 Government bonds according to the holder (on 30 November 2017)

\begin{tabular}{|c|c|c|c|}
\hline & Holder & CZK & in\% \\
\hline 11000 & Non-financial companies & 13790710030 & 0.86 \\
\hline 12000 & Financial companies & 732271590000 & 45.76 \\
\hline 12200 & $\begin{array}{l}\text { An institution receiving deposits except for the } \\
\text { central bank }\end{array}$ & 341882080000 & 21.37 \\
\hline 12203 & $\begin{array}{l}\text { A foreign institution receiving deposits except for the } \\
\text { central bank }\end{array}$ & 311514820000 & 19.47 \\
\hline 12800 & Insurance companies & 122675320000 & 7.67 \\
\hline 12803 & Foreign insurance companies & 121797510000 & 7.61 \\
\hline 12900 & Pension funds & 228190490000 & 14.26 \\
\hline 12903 & Foreign pension funds & 228151240000 & 14.26 \\
\hline 13000 & Agency of government & 34228787180 & 2.14 \\
\hline 14000 & Households & 29582079479 & 1.85 \\
\hline 15000 & Non-profit institutions & 1478182340 & 0.09 \\
\hline \multirow[t]{3}{*}{20000} & Non-residents & 586376784847 & 36.65 \\
\hline & Total government bonds & 1600116483876 & 100 \\
\hline & Holder & CZK & in $\%$ \\
\hline 11000 & Non-financial companies & 13790710030 & 0.86 \\
\hline 12000 & Financial companies & 732271590000 & 45.76 \\
\hline 12200 & Institution receiving deposits except the central bank & 341882080000 & 21.37 \\
\hline 12203 & $\begin{array}{c}\text { Foreign institution receiving deposits except the } \\
\text { central bank }\end{array}$ & 311514820000 & 19.47 \\
\hline 12800 & Insurance companies & 122675320000 & 7.67 \\
\hline 12803 & Foreign insurance companies & 121797510000 & 7.61 \\
\hline 12900 & Pension funds & 228190490000 & 14.26 \\
\hline 12903 & Foreign pension funds & 228151240000 & 14.26 \\
\hline 13000 & Agency of government & 34228787180 & 2.14 \\
\hline 14000 & Households & 29582079479 & 1.85 \\
\hline 15000 & Non-profit institutions & 1478182340 & 0.09 \\
\hline \multirow[t]{2}{*}{20000} & Non-residents & 586376784847 & 36.65 \\
\hline & Total government bonds & 1600116483876 & 100 \\
\hline
\end{tabular}

Source: Bonds according to the holder. Ministry of Finance.

Table 7 shows that financial companies (especially foreign banks and foreign pension companies) are the main holders of bonds. The second group creates nonresidents. These subjects gain profits from holding the bonds. By contrast, every 
citizen has to pay interests connected with bonds through increasing state incomes (that means taxes).

\section{Conclusions}

State prefer only pension insurance at the pension companies. The other possibilities of insurance for old-age are not supported with state contributions. The number of pension companies shows that the number is enough for creating of competition and enough for the stability of every company on the market. Pension companies gain money by the participants of pension insurance and money, which the state send to participants of pension insurance for increasing of your motivation to save. Pension companies can increase their profit through the money from the state. State contributions per pension are still increasing and create more than 6,8 milliard CZK per a year. According to the analysis of pension companies, the most part of these is owned by foreign owners and returns are transferred to the foreign countries. Pension companies invest especially in the bonds that contribute to redistribution incomes in the society. The pension companies have these advantages in comparison with companies doing different business:

- Pension companies can buy some bonds or stock, which are offered, only in big volume. Foreign capital increases the profit of own capital. That is the principle of the financial arm.

- More money allows negotiating better conditions of contracts or investments for pension companies.

- Pension companies receive money by participants of pension insurance and state regularly once per month. Pension companies do not often have embarrassments with gaining the payments in comparison with the companies doing different business.

- Participants in pension insurance close the contract for a long period. Table 2 shows that the number of pension insurance is still high, it is possible to deduce that contracts are not often canceled.

- The state determines the level of state contributions for pension insurance and level of the fee for administration money in pension funds. Increasing of administration fee and decreasing rewards for returns of pension funds can be the reason for low motivation for increasing of profit of pension funds.

All these comments show that pension companies should have a high level of financial stability and profitability. The most participants choose the conservative type of pension funds. Returns of this pension funds are low for this reason. It 
is a question if the monies will be enough for paying pensions in the future and balanced with current expenditures.

\section{References}

Hovorka, J.: Spoření na důchod podraží. Vyděláte na tom, slibují ale penzijní společnosti (Saving for pension will be more expensive. Pension companies promise that we will earn on that), 2017. www.zpravy.aktualne.cz.

Slapnička, M.: Státní dluhopisy prodělávají, penzijní společnosti se jich zbavují (Government bonds lose, pension companies sell them), 2017. www.nasepenize.cz.

Tůma, O.: Doplňkové penzijní spoření. Jak si letos vede nové penzijko (Supplementary pension companies. How does new pension insurance work this year), 2017. www.penize.cz.

Tůma, O.: Velké srovnání výsledků fondů doplňkového penzijního spoření za rok 2016 (Big comparison of supplementary pension funds in 2016), 2017. www.penize.cz.

Association of Pension Companies in the Czech Republic, 2017. www.apfcr.cz.

Annual Report of Allianz penzijní společnost 2016, 2017. www.allianz.cz.

Annual Report of Axa penzijní společnost 2016, 2017. www.axa.cz.

Annual Report of Conseq penzijní společnost 2016, 2017. www.conseq.cz.

Annual Report of ČSOB penzijní společnost 2016, 2016. www.csob-penze.cz.

Annual Report of Česká spořitelna penzijní společnost 2016, 2017. www.csps.cz.

Annual Report of KB Penzijní společnost 2016, 2017. www.kbps.cz.

Annual Report of NN Penzijní společnost 2016, 2017. www.nn.cz.

Annual Report of Penzijní společnost České pojištovny 2016, 2017. www.pfcp.cz.

Basic indexes of development of pension insurance, Ministry of Finance of the Czech Republic, 2017. www.mfcr.cz.

Bonds according to the holder, Ministry of Finance, 2017. www.mfer.cz.

Czech Social Security Administration, 2017. www.cssz.cz.

Pension Funds Online, 2017. www.pensionfundsonline.co.uk.

CZ: Act no. 42/1994 Coll., on State-Contributory Supplementary Pension Insurance.

CZ: Act no. 155/1995 Coll., on pension insurance.

CZ: Act no. 427/2011 Coll., on Supplementary Pension Savings. 